\title{
PREPARATION AND NUCLEOPHILIC SUBSTITUTION OF THE 2,4,6- TRIPHENYLPYRIDINIUM SALTS, DIAZONIUM INTERMEDIATES AND $N, N$-1,2-BENZENEDISULFONYLIMIDES OF CHIRAL AMINO ACIDS
}

\author{
SA Said \\ Department of Chemical and Environmental Marine Sciences, University of Dar es Salaam, P.O. \\ Box 668, Zanzibar, Tanzania
}

\begin{abstract}
Three methods for preparation of D-amino acids by nucleophilic substitution on derivatives of their L-antipodes have been attempted. Nucleophilic substitution on optically active phenylalanine ethyl ester triphenylpyridinium salt yielded partial inverted azide products. The $N, N$-disulfonylimide intermediate of the same ester was synthesized in high yield and optical purity, but the substitution reaction on this compound was not achieved. Diazotization of amino acid ammonium chlorides and tosylates in solution of sodium azide in aprotic solvents gave optically active chloro and tosyl compounds instead of the intended azide products. Alternative methods to circumvent the problem of the competing ammonium salt counterions during diazotization reactions have been suggested.
\end{abstract}

\section{INTRODUCTION}

In recent years, the preparation of nonproteinogenic amino acids has received much attention because their inclusion in peptides often results in interesting bioactivity of the peptide (Wenger 1985, Bajusz et al 1988, Benatowicz et al 1996, Drauz 1997). Among the important nonproteinogenic amino acids are the $\mathrm{D}$-isomer of the natural L- $\alpha$-amino acids (Drauz 1997). Asymmetric methods used to produce L- $\alpha$-amino acids can be utilized for the production of their D-isomers by inverting the chirality of the asymmetric addend used in the process (Williams 1989, Williams and Hendrix 1992, Rutjes et al 2000). An alternative approach for producing $\mathrm{D}-\alpha$-amino acids is by inversion of the readily available $\mathrm{L}-\alpha$-amino acids via stereoselective nucleophilic substitution reactions. Activation and subsequent substitution of $\alpha$-amino acids present a real challenge due to racemization problem caused by their $\alpha$-proton propensity to deprotonating agents. As a consequence inversion of amino acids has attracted less attention. However, some investigations towards this goal have been reported. For example, Hoffman and Kim (1992) have prepared protected $\alpha$-amino esters with complete inversion of configuration via a four step reaction sequence. Although this sequence gives complete inversion of configuration, it suffers from the disadvantages of low yields due to a large number of steps involved in the whole pathway. It is therefore worthwhile to investigate a more simple method for direct inversion of the L- $\alpha$-amino acids to their Dantipodes. Since we have developed a number of general methods for inversion of chiral amines (Said and Fiksdahl 2001a), it was thus decided to apply some of these methods on inversion of amino acids.

\section{MATERIALS AND METHODS}

\section{General}

All chemicals and solvents used were of synthetic grade unless otherwise noted. 2,4,6-Triphenylpyrylium tetrafluoroborate, L-alanine ethyl ester hydrochloride, Lphenylalanine ethyl ester hydrochloride and L-valine benzyl ester toluene-4-sulfonate were obtained from Fluka, sodium azide from Merck and potassium nitrite, acetic acid and triethylamine were purchased from Acros. 1,2-Benzenedisulfonylchloride was prepared as described elsewhere (Sorbye et al 1998). DME and THF were distilled under nitrogen from sodium benzophenone ketyl 
Said - Preparation and nucleophilic substitution ...

and used immediately. DMF and dichloromethane were distilled over $\mathrm{CaH}_{2}$. GLC: Carlo Erba Model 8130, splitinjection, hydrogen, FID, column: Chrompack CP-Sil 5 CB $(25 \mathrm{~m})$. Chiral GLC analysis: Chrompack CP-CHIRADEXCB fused silica WCOT $(25 \mathrm{~m}, 0.32 \mathrm{~mm}$; $0.32 \mu \mathrm{m})$, carrier gas pressure 5.5 .5 p.s.i. 1-

H/13-C NMR: Bruker Avance DPX 300/75.47 MHz and 400/100.61 $\mathrm{MHz}$ spectrometers, chemical shifts are reported in ppm downfield from TMS. MS: MAT 95 XL. IR: Nicolet 20SXC FT-IR spectrometer. $[\alpha]_{\mathrm{D}}$ : Perkin_Elmer 241 polarimeter $(10 \mathrm{~cm}$ cell with a total volume of $1 \mathrm{~mL}$ ). X-ray: Enraf-Nonius CAD-4 diffractometer.

\section{2,4,6-Triphenylpyridinium salt of phenylalanine ethyl ester (3)}

Method A: To a suspension of phenylalanine ethyl ester hydrochloride (1) (574 mg, $2.5 \mathrm{mmol}$ ) and 2,4,6-triphenylpyrylium tetrafluoroborate (2) (1.0 $\mathrm{g}, 2.5 \mathrm{mmol})$ in $\mathrm{CH}_{2} \mathrm{Cl}_{2}$ was added triethylamine $(0.69 \mathrm{~mL}, 5.0 \mathrm{mmol})$ and the mixture was stirred at $\mathrm{rt}$ for $15 \mathrm{~min}$. Acetic acid $(0.29 \mathrm{~mL}, 5 \mathrm{mmol})$ was added, and the mixture was further stirred for $5 \mathrm{~h}$ at $\mathrm{rt}$ under nitrogen. The solvent was stripped off, and the crude product was purified by flash chromatography (gradient elution: d i c h lor o m e th a n e, $\quad 5 \%$ methanol/dichloromethane) to yield a white crystalline pyridinium tetrafluoroborate $\mathbf{3}$ (1.35 g, 96\%); mp 198-199 ${ }^{\circ} \mathrm{C} ;{ }^{1} \mathrm{H}$ NMR $\left(400 \mathrm{MHz}, \mathrm{CDCl}_{3}\right): \delta 1.18(\mathrm{t}, \mathrm{J}=7 \mathrm{~Hz}$, $3 \mathrm{H}), 2.85(\mathrm{dd}, \mathrm{J}=14$ and $8 \mathrm{~Hz}, 1 \mathrm{H}), 3.46$ $(\mathrm{dd}, \mathrm{J}=14$ and $4 \mathrm{~Hz}, 1 \mathrm{H}), 4.1(\mathrm{~m}, 2 \mathrm{H})$, $5.63(\mathrm{dd}, \mathrm{J}=8$ and $4 \mathrm{~Hz}, 1 \mathrm{H}), 6.77(\mathrm{~m}$, 2H), $7.08(\mathrm{~m}, 3 \mathrm{H}), 7.53(\mathrm{~m}, 11 \mathrm{H}), 7.83(\mathrm{~m}$, 4H), 7.94 (s, 2H) ${ }^{13} \mathrm{C}$ NMR $(100.61 \mathrm{MHz}$, $\left.\mathrm{CDCl}_{3}\right)$ : $\quad$ 16.80, 40.77, 66.62, 73.58, $130.30,130.97,131.68,132.15,132.23$, $132.83,134.63,135.52,136.87,139.57$, 160.08, 170.89; MS [m/z (rel. int.)]: 483 $\left(\mathrm{M}-\mathrm{BF}_{4}, 15 \%\right), 410(33 \%), 307\left(\mathrm{Ph}_{3} \mathrm{Pyr}\right.$, $100 \%), 230(18 \%), 202(12 \%), 176(2 \%)$, 104 (11\%), 91 (12\%), 77 (6\%); IR (KBr, $\mathrm{cm}^{-1}$ ): $3064(\mathrm{w}), 2960$ (w), 1755 (s), 1737 (s), $1621(\mathrm{~s}) 1598(\mathrm{~m}), 1562(\mathrm{~m}), 1553(\mathrm{~m})$, $1494(\mathrm{~m}), 1447$ (m), 1415 (w), 1381 (w), $1240(\mathrm{~m}), 1216(\mathrm{~m}), 1083$ (s), $1058(\mathrm{~s})$, 1037 (s), 890 (w), 851 (w), 762 (s), 704 (s), $695(\mathrm{~s}) ;[\alpha]_{\mathrm{D}}=-1.75\left(\mathrm{c}=2, \mathrm{CHCl}_{3}\right)$.

Method B: A solution of phenylalanine ethyl ester (1) (1.00 g, $5.2 \mathrm{mmol})$ in THF (3 $\mathrm{mL}$ ) was added to a yellow solution of 2,4,6-triphenylpyrylium tetrafluoroborate (2) (1.03 g, $2.6 \mathrm{mmol}, 1 / 2$ eq.). The mixture was stirred and heated to $50{ }^{\circ} \mathrm{C}$ for $48 \mathrm{~h}$ under nitrogen. Compound $\mathbf{3}$ was obtained in $67 \%$ yield using the usual work up and it was found to be optically inactive. Method C: Method B was repeated, but acetic acid $(0.1$ eq) was added after addition of phenylalanine ethyl ester and 20 minutes of stirring. The reaction was complete after 7 days of stirring at room temperature. These conditions yielded only $48 \%$ of compound $3 ;[\alpha]_{\mathrm{D}}=-2.25\left(\mathrm{c}=2, \mathrm{CHCl}_{3}\right)$.

\section{2-Azido-3-phenylpropionic acid ethyl ester (4)}

2,4,6-Triphenylpyridinium tetrafluoroborate (3) (2.5 g, $4.4 \mathrm{mmol}$ ) and $\mathrm{NaN}_{3}$ (1.0 g, 15.4 $\mathrm{mmol})$ in DMF were stirred and heated to $80{ }^{\circ} \mathrm{C}$ for $8 \mathrm{~h}$ under nitrogen atmosphere. The mixture was cooled to room temperature, diluted with water, extracted with diethyl ether and washed with brine. The solution was dried over $\mathrm{Na}_{2} \mathrm{SO}_{4}$. Evaporation of solvent in vacuo gave an oily product, which was purified by flash chromatography (silica gel, $1 \%$ acetone/heptane) to yield compound $\mathbf{4}$ as a colorless oil (701 mg, 73\%); ${ }^{1} \mathrm{H}$ NMR (400 $\left.\mathrm{MHz}, \mathrm{CDCl}_{3}\right): \delta 1.26(\mathrm{t}, \mathrm{J}=7 \mathrm{~Hz}, 3 \mathrm{H})$, $3.03(\mathrm{dd}, \mathrm{J}=14$ and $9 \mathrm{~Hz}, 1 \mathrm{H}), 3.17(\mathrm{dd}, \mathrm{J}$ $=14$ and $6 \mathrm{~Hz}, 1 \mathrm{H}), 4.03(\mathrm{dd}, \mathrm{J}=9$ and 6 $\mathrm{Hz}, 1 \mathrm{H}), 4.21(\mathrm{q}, \mathrm{J}=7 \mathrm{~Hz}, 2 \mathrm{H}), 7.28(\mathrm{~m}$, $5 \mathrm{H}) ;{ }^{13} \mathrm{C}$ NMR $\left(75.47 \mathrm{MHz}, \mathrm{CDCl}_{3}\right)$ : $14.28, \quad 37.82, \quad 62.07,63.41, \quad 127.41$, $128.83,129.39,136.16,170.12 ; \mathrm{MS}[\mathrm{m} / \mathrm{z}$ (rel. int.)]: $219\left(\mathrm{M}^{+}, 0.9 \%\right), 176(63 \%) 148$ (3\%), $131(3 \%), 118(9 \%), 91$ (100\%); IR (neat, $\left.\mathrm{cm}^{-1}\right)$ : $3031(\mathrm{w}), 2983$ (w), 2111 (s), 1741 (s), 1594 (w), 1549 (w), 1497 (m), 1455 (m), 1263 (s), 1197 (s), 1029 (m), 755 $(\mathrm{m}), 699(\mathrm{~s}) ;[\alpha]_{\mathrm{D}}=-2.15\left(\mathrm{c}=2, \mathrm{CHCl}_{3}\right)$. 


\section{2-Chloro-3-phenylpropionic acid ethyl ester (9)}

Tertiary butyl nitrite [(90\%), $0.86 \mathrm{ml}, 7.2$ mmol] was added to a stirred solution of phenylalanine ethyl ester hydrochloride (1) $(1.0 \mathrm{~g}, 4.4 \mathrm{mmol})$ and $\mathrm{NaN}_{3}(0.85 \mathrm{~g}, 13.1$ $\mathrm{mmol})$ in DME $(10 \mathrm{~mL})$. The mixture was stirred at $\mathrm{rt}$ under nitrogen atmosphere until the evolution of gas ceased $(30 \mathrm{~min})$. The solution was filtered, and the residue washed with diethyl ether. The yellowish oily product obtained after removal of solvent was purified by flash chromatography to give compound $9(850 \mathrm{mg}, 92 \%)$ as a colourless oil. ${ }^{1} \mathrm{H} \mathrm{NMR}\left(300 \mathrm{MHz}, \mathrm{CDCl}_{3}\right)$ : $\delta 1.25(\mathrm{t}, \mathrm{J}=7 \mathrm{~Hz}, 3 \mathrm{H}), 3.21(\mathrm{dd}, \mathrm{J}=14$ and $7 \mathrm{~Hz}, 1 \mathrm{H}), 3.41(\mathrm{dd}, \mathrm{J}=14$ and $7 \mathrm{~Hz}$, $1 \mathrm{H}), 4.19$ (q, J = $7 \mathrm{~Hz}, 2 \mathrm{H}), 4.46$ (t, $\mathrm{J}=7$ $\mathrm{Hz}, 1 \mathrm{H}), 7.3(\mathrm{~m}, 5 \mathrm{H}) ;{ }^{13} \mathrm{C}$ NMR $(75.47$ $\left.\mathrm{MHz}, \mathrm{CDCl}_{3}\right)$ : $14.02,41.20,57.53$, $62.09,127.40, \overline{1} 28.66,129.44,136.03$, 169.26; MS [m/z (rel. int.)]: $212(2 \%), 177$ $(39 \%), 176$ (35\%), $141(10 \%), 139$ (M $\left.\mathrm{EtCO}_{2}, 30 \%\right), 131(100 \%), 103(61 \%), 91$ (73\%), 77 (33\%), $29(24 \%), 28$ (45\%); IR (neat, $\left.\mathrm{cm}^{-1}\right): 3031(\mathrm{w}), 2983(\mathrm{~m}), 1742$ (s), 1498 (m), 1454 (m), 1391 (w), 1371 (m), 1294 (s), 1238 (m), 1178 (s), 1162 (s), 1030 $(\mathrm{m}), 747(\mathrm{~m}), 698(\mathrm{~s}) ;[\alpha]_{\mathrm{D}}=+2.1(\mathrm{c}=2$, $\mathrm{CHCl}_{3}$ ); HRMS: calculated for $\mathrm{C}_{11} \mathrm{H}_{13} \mathrm{ClO}_{2}$ : 212.0604; observed: 212.0603 .

\section{2-Chloropropionic acid ethyl ester (12)}

Tertiary butyl nitrite [(90\%), $0.32 \mathrm{~mL}, 2.4$ mmol] was added to a stirred solution of alanine ethyl ester hydrochloride (10) (250 $\mathrm{mg}, 1.6 \mathrm{mmol})$ and $\mathrm{NaN}_{3}(317 \mathrm{mg}, 4.9$ $\mathrm{mmol})$ in DME $(5 \mathrm{~mL})$. The mixture was stirred at $\mathrm{rt}$ under nitrogen atmosphere until the evolution of gas ceased $(30 \mathrm{~min})$. The solution was filtered and the residue washed with diethyl ether. The yellowish oily product obtained after removal of solvent was purified by flash chromatography to give compound $12(200 \mathrm{mg}, 90 \%)$ as a colourless oil. ${ }^{1} \mathrm{H}$ NMR (300 $\left.\mathrm{MHz}, \mathrm{CDCl}_{3}\right)$ : ठ $1.31(\mathrm{t}, \mathrm{J}=7 \mathrm{~Hz}, 3 \mathrm{H}), 1.68(\mathrm{~d}, \mathrm{~J}=7 \mathrm{~Hz}$, $3 \mathrm{H}), 4.23$ (q, J = $7 \mathrm{~Hz}, 2 \mathrm{H}), 4.40(\mathrm{~J}=7 \mathrm{~Hz}$, $1 \mathrm{H}) ;{ }^{13} \mathrm{C}$ NMR $\left(75.47 \mathrm{MHz}, \mathrm{CDCl}_{3}\right)$ : $14.04,21.52,52.61,62.06,170.12 ; \mathrm{MS}$ [m/z (rel. int.)]: $137(4 \%), 136(2 \%), 135$ (13\%), $101(15 \%), 93(30 \%), 91(100 \%), 73$ (11\%), $65(23 \%), 63(71 \%), 57(56 \%), 55$ (44\%), 29 (77\%); IR (neat, $\left.\mathrm{cm}^{-1}\right): 2984$ (m), 1743 (s), 1447 (m), 1373 (m), 1302 (w), 1270 (s), 1184 (s), 1143 (s), 1074 (m), 1021 (m), $992(\mathrm{w}) 858(\mathrm{w}) 691(\mathrm{w}) ;[\alpha]_{\mathrm{D}}=+5.1$ (c $\left.=2, \mathrm{CHCl}_{3}\right)$; HRMS: calculated for $\mathrm{C}_{5} \mathrm{H}_{9} \mathrm{ClO}_{2}$ : 136.0291; observed: 136.0289 .

\section{3-Methyl-2-(toluene-4-sulfonyloxy)- butyric acid ethyl ester (16)}

Tertiary butyl nitrite [(90\%), $0.26 \mathrm{ml}, 2.0$ $\mathrm{mmol}$ ] was added to a stirred solution of Lvaline benzyl ester toluene-4-sulfonate (14) (500 mg, $1.3 \mathrm{mmol})$ and $\mathrm{NaN}_{3}(300 \mathrm{mg}, 4.6$ $\mathrm{mmol})$ in DME $(10 \mathrm{~mL})$. The mixture was stirred at $\mathrm{rt}$ for $3 \mathrm{~h}$ under nitrogen atmosphere. The reaction mixture was then filtered and the residue washed with dichloromethane. The yellowish oily product obtained after removal of solvent was purified by flash chromatography (3\% acetone/heptane) to give compound 16 (209 $\mathrm{mg}, 44 \%$ ) as a colourless oil. ${ }^{1} \mathrm{H}$ NMR (300 $\left.\mathrm{MHz}, \mathrm{CDCl}_{3}\right): \delta 0.87(\mathrm{~d}, \mathrm{~J}=4 \mathrm{~Hz}, 3 \mathrm{H})$, $0.89(\mathrm{~d}, \mathrm{~J}=4 \mathrm{~Hz}, 3 \mathrm{H}), 2.20(\mathrm{~m}, 1 \mathrm{H}), 2.42$ $(\mathrm{s}, 3 \mathrm{H}), 4.68(\mathrm{~d}, \mathrm{~J}=5 \mathrm{~Hz}, 1 \mathrm{H}), 5.06(\mathrm{~s}$, 2H), $7.34(\mathrm{~m}, 8 \mathrm{H}), 7.77(\mathrm{~d}, \mathrm{~J}=8 \mathrm{~Hz}, 2 \mathrm{H})$; ${ }^{13} \mathrm{C}$ NMR $\left(75.47 \mathrm{MHz}, \mathrm{CDCl}_{3}\right)$ : 17.16 , $18.48,21.91,31.34,67.38,82.27,128.31$, $128.58,128.72,128.79,129.90,133.39$, 135.15, 145.14, 168.44; MS [m/z (rel. int.)]: $362\left(\mathrm{M}^{+}, 0.11 \%\right), 279(2.79 \%), 256$ (7.71\%), $227(6.47 \%), 155(96.76 \%), 107$ $(8.61 \%), 91(100 \%)$; IR (neat, $\left.\mathrm{cm}^{-1}\right): 3034$ (w), 2989 (w), 1757 (s), 1455 (w), 1370 (m), 1276 (m), 1177 (s), 997 (s), 839 (m), $697(\mathrm{w}) ;[\alpha]_{\mathrm{D}}=+3.6\left(\mathrm{c}=2, \mathrm{CHCl}_{3}\right)$.

\section{$N, N$-Benzene-1,2-disulfonylimide derivative of $L$-phenylalanine ethyl ester (18)}

Benzene-1,2-disulfonyl chloride 17 (4.5 g, $16.4 \mathrm{mmol})$ was dissolved in methylene chloride $(400 \mathrm{ml})$ and brought to reflux. A solution of L-phenylalanine ethyl ester hydrochloride $1(2.5 \mathrm{~g}, 10.9 \mathrm{mmol})$ and triethylamine $(4.8 \mathrm{~mL}, 34.6 \mathrm{mmol})$ in methylene chloride $(150 \mathrm{~mL})$ was added 
slowly over 50 hours at a rate of $3 \mathrm{~mL} / \mathrm{h}$. The reaction was refluxed for another 3 hours. The solvent was removed in vacuo to yield $10.52 \mathrm{~g}$ of the off-white crystalline crude product. Triethylamine hydrochloride and excess benzene-1,2-disulfonyl chloride were separated from the product by flash chromatography (silica gel, dichloromethane) to yield $3.80 \mathrm{~g}$ (88\%) of compound 18. M.p. $130-132^{\circ} \mathrm{C}$. ${ }^{1} \mathrm{H}$ NMR $\left(300 \mathrm{MHz}, \mathrm{CDCl}_{3}\right): \delta 0.90(\mathrm{t}, \mathrm{J}=7 \mathrm{~Hz}$, $3 \mathrm{H}), 3.42(\mathrm{dd}, \mathrm{J}=15$ and $11 \mathrm{~Hz}, 1 \mathrm{H}), 3.72$ $(\mathrm{dd}, \mathrm{J}=5$ and $15 \mathrm{~Hz}, 1 \mathrm{H}), 4.03(\mathrm{q}, \mathrm{J}=7$ $\mathrm{Hz}, 2 \mathrm{H}), 4.95(\mathrm{dd}, \mathrm{J}=11$ and $5 \mathrm{~Hz}, 1 \mathrm{H})$, 7.35 (m, $5 \mathrm{H}), 7.84(\mathrm{~m}, 2 \mathrm{H}), 7.92(\mathrm{~m}, 2 \mathrm{H})$; ${ }^{13} \mathrm{C}$ NMR $\left(75.47 \mathrm{MHz}, \mathrm{CDCl}_{3}\right)$ : 13.60 , $36.92, \quad 62.42,63.78, \quad 121.75, \quad 127.47$, $128.96,129.57,134.42,136.44,138.30$ 168.04; MS [m/z (rel. int.)]: $395\left(\mathrm{M}^{+}\right.$, $0.1 \%), 322(13 \%), 304(6 \%), 232$ (5\%), 220 (1.4), $176(100 \%), 148(15 \%), 131(21 \%)$, 104 (4\%), $91(56 \%)$; IR (KBr, cm $\left.{ }^{-1}\right): 3094$ (m), $3060(\mathrm{w}), 2976(\mathrm{~m}), 1744(\mathrm{~s}), 1447$ (m), 1372 (s), 1200 (s), 1173 (s), 1074 (m), $949(\mathrm{~m}), 901(\mathrm{~m}), 819(\mathrm{~m}), 762$ (s) $744(\mathrm{~s})$, $697(\mathrm{~s}), 627(\mathrm{~m}), 591(\mathrm{~s}), 557(\mathrm{~s}), 505(\mathrm{~m})$; $[\alpha]_{\mathrm{D}}=-60.66\left(\mathrm{c}=1, \mathrm{CHCl}_{3}\right)$.

\section{RESULTS AND DISCUSSION \\ Inversion of amino acids via $2,4,6-$ triphenylpyridinium salts}

The first attempt in the effort to invert the $\mathrm{L}-\alpha$-amino acids to their D-isomers was the us e of 2,4,6-triphenylpyridinium derivatives. These compounds are known to be valuable intermediates in nucleophilic substitution of primary and secondary amines (Katritzky et al 1979, Katritzky et al 1983). We have recently reported their use in inversion of chiral amines (Said and Fiksdahl 2001b). Triphenylpyridinium salts are thermally stable and are very reactive towards various nucleophiles. Intermediate 2,4,6-triphenylpyridinium salt $\mathbf{3}$ was prepared from 2,4,6-triphenylpyrylium tetrafluoroborate (2) and (L)-phenylalanine ethyl ester hydrochloride (1) (Scheme 1) in $96 \%$ yield. The reaction was catalyzed by acetic acid and used one extra equivalent of triethylamine to deprotonate the substrate, (S)-phenylalanine ethyl ester hydrochloride (1) before it could attack the 2,4,6triphenylpyrylium cation 2 (Scheme 1).<smiles>CCOC(=O)C([NH3+])Cc1ccccc1</smiles><smiles>F[P+](F)c1cc(-c2ccccc2)cc(-c2ccccc2)c1</smiles><smiles>CCOC(=O)C(Cc1ccccc1)[n+]1c(-c2ccccc2)cc(-c2ccccc2)cc1[P+](F)(F)F</smiles>

Scheme 1: Preparation of 2,4,6-triphenylpyridinium salt of (S)-phenylalanine ethyl ester(3).

The nucleophilic displacement of compound (3) by sodium azide afforded moderate yields of the azide substitution product 4 . However, the stereoselectivity of the substitution reaction was dissatisfying; the products showed only $58 \%$ inversion (Table 1 , method A).

The poor stereoselectivity of this procedure might be caused by racemization of the pyridinium salt $\mathbf{3}$ during preparation or could be the consequence of the nucleophilic substitution reaction. In case of the first presumption, racemization of $\mathbf{3}$ might have happened via acid mediated tautomerization of the vinylogous compound $\mathbf{5}$, an intermediate formed during preparation of the triphenylpyridinium salt (Scheme 2). 
Table 1: $\quad$ Preparation and nucleophilic substitution of 2,4,6-triphenylpyridinium salt of (S)phenylalanine ethyl ester<smiles>CCOC(=O)[C@@H](Cc1ccccc1)[Si]Cl</smiles>

\begin{tabular}{|c|c|c|c|c|}
\hline Method & $\begin{array}{l}\text { Reaction condition Step I } \\
\text { (yield } \% \text { ) }\end{array}$ & $\begin{array}{l}\text { Optical activity for } \mathbf{3} \\
{[\alpha]_{\mathrm{D}}\left(\mathrm{c}=2, \mathrm{CHCl}_{3}\right)}\end{array}$ & $\begin{array}{c}\mathbf{4} \\
\text { yield }(\%)\end{array}$ & $\begin{array}{l}\text { Degree of } \\
\text { inversion } \\
\text { for } 6\end{array}$ \\
\hline A & $\begin{array}{l}\mathrm{Et}_{3} \mathrm{~N} \text { (2 eq.), HOAc, } \\
\mathrm{CH}_{2} \mathrm{Cl}_{2}, \mathrm{rt}, 5 \text { h (96) }\end{array}$ & -1.75 & 73 & $58 \%$ \\
\hline B & $\begin{array}{l}1 \text { (2 eq.), THF, reflux, } 48 \mathrm{~h} \\
\text { (67) }\end{array}$ & 0 & - & \\
\hline $\mathrm{C}$ & $\begin{array}{l}1 \text { (2 eq.), HOAc ( } 0.1 \text { eq.), } \\
\mathrm{CH}_{2} \mathrm{Cl}_{2}, \mathrm{rt}, 7 \text { days }(48)\end{array}$ & -2.25 & 64 & $67 \%$ \\
\hline
\end{tabular}

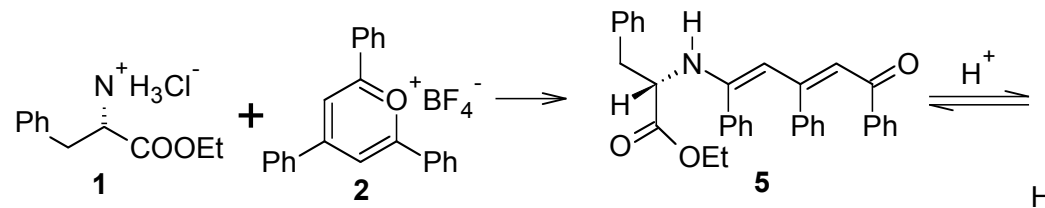<smiles>CCOC(=O)C(Cc1ccccc1)C(Cc1ccccc1)NC(=CC(=CCc1ccccc1)c1ccccc1)c1ccccc1</smiles><smiles>CCOC(=O)C(Cc1ccccc1)N/C(=C\C(=C/Cc1ccccc1)c1ccccc1)C(O)=C(Cc1ccccc1)c1ccccc1</smiles>

Racemic 3

Scheme 2: $\quad$ Proposed mechanism for racemization of (S)-phenylalanine ethyl ester vinylogous intermediate 5.

The presence of excess base may also cause racemization of the pyridinium salt itself once it has been formed from its individual constituents (Scheme 3). In order to rectify this apparent problem we sought to avoid the use of both triethylamine and acetic acid. Since the presence of a base is necessary in this reaction, the amino acid $(S)-\mathbf{1}$ was deprotonated and used in excess amount (2 equivalents). Compound 3 could not be formed under these conditions except at elevated temperatures or by adding small amounts of the acetic acid. Neither of these strategies improved the stereoselectivity of this process (Table 1: methods $\mathrm{B}$ and $\mathrm{C}$ ). Once again, the failure of these procedures is presumably due to racemization of $\mathbf{3}$ via 
tautomerization or the resonance stabilized iminium ion mechanism (Scheme 3). The methine proton in $\mathbf{3}$ can be easily abstracted even by a weak base especially at elevated temperatures to form a carbanion $\mathbf{6}$, which can racemize via either tautomer 7 or an iminium ion 8 (Scheme 3). The use of small amounts of acetic acid required long reaction times. Racemization of the vinylogous intermediate 5 or the pyridinium salt $\mathbf{3}$ could therefore not be ruled out under these conditions.<smiles>CCOC(=O)[C@H](Cc1ccccc1)[n+]1c(-c2ccccc2)cc(-c2ccccc2)cc1-c1ccccc1</smiles>

3

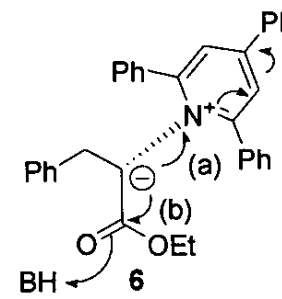<smiles>CCOC(=O)/C(Cc1ccccc1)=[N+]1\C=CC(c2ccccc2)C=C1c1ccccc1</smiles>

(a)<smiles>C1=CC1</smiles><smiles>C(=NC(=Cc1ccccc1)c1ccccc1)c1ccccc1</smiles>

b)<smiles>CCOC(O)=C(Cc1ccccc1)[n+]1c(-c2ccccc2)cc(-c2ccccc2)cc1-c1ccccc1</smiles>

Scheme 3: $\quad$ Proposed mechanism for base catalyzed racemization of the pyridinium salt of (S)phenylalanine ethyl ester 3 .

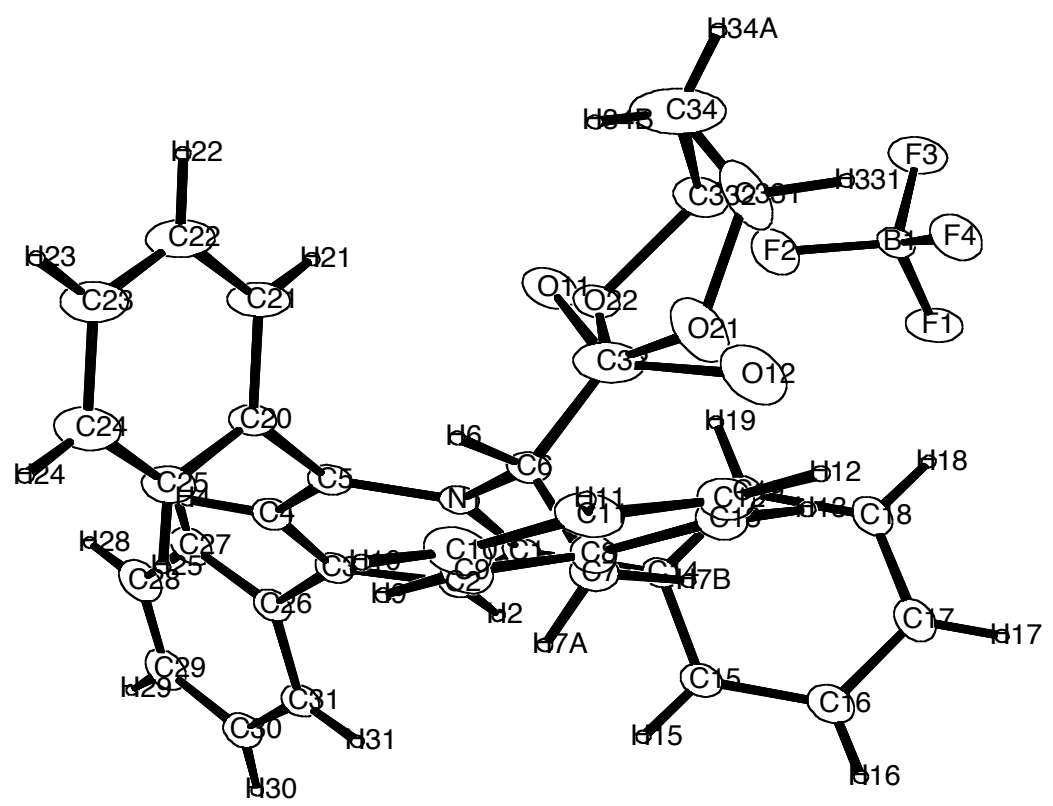

Figure 1: $\quad$ X-ray structure of compound 3. 
Evidence for tautomerization of the pyridinium salt 3 could be obtained via Xray crystallography. The length of the C6$\mathrm{C} 32$ bond in X-ray structure of the tautomer between compound 3 and 7 should lie between a single and a double bond. The Xray data for 3 (Figure 1) was ambiguous due to the rolling of the $\mathrm{BF}_{4}$ group throughout the crystal structure and the appearance of the two conformers of the ester moiety in the X-ray structure. However, the observed value (1.479 $\AA$ ) does not fit for the standard single or double bond lengths and could be positioned between these two values, which indicates the tautomerization phenomenon in the pyridinium salt 3 .

\section{Inversion of amino acids via diazonium} salts

Our next investigations were focused on diazonium intermediates. In this approach, diazotization reactions were carried out in aprotic solvents in the presence of nucleophiles to facilitate a coupled diazotization-dediazoniation process in a one-pot reaction. In a typical example Lphenylalanine ethyl ester hydrochloride (1) (Scheme 4) was diazotized in the presence of sodium azide using tertiary butyl nitrite in DME. The coupled diazotizationsubstitution reaction of L-phenylalanine ethyl ester hydrochloride (1) in DME (Scheme 4) gave only one product. Spectroscopic analysis of this compound showed that the desired azide product $\mathbf{4}$ has not been formed and a chloro substituent $\mathbf{9}$ has been synthesized instead. Alanine ethyl ester hydrochloride (10) (Scheme 4) gave similar results, the chloro product $\mathbf{1 2}$ was isolated in high yields (Table 2) instead of the expected azide product 11 .

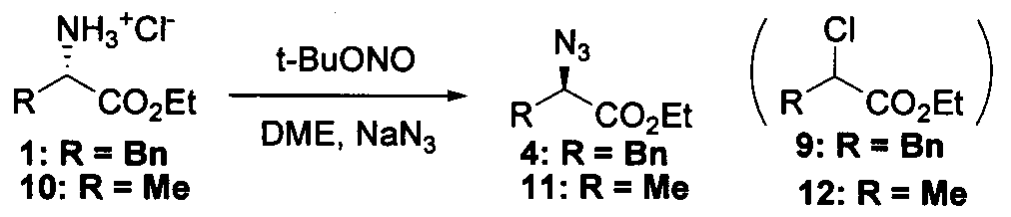

Scheme 4: Diazotization of L-alanine and L-phenylalanine ethyl esters 1 and $\mathbf{1 0 .}$

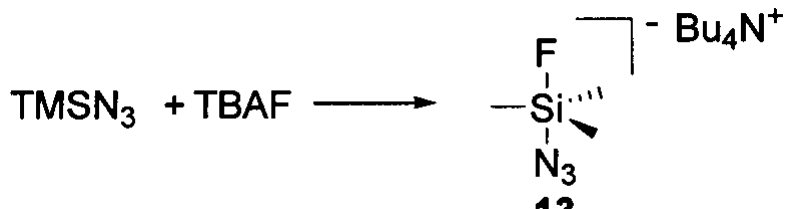

Scheme 5: Formation of soluble azide from trimethylsilylazide and tertiary butylammonium fluoride.

Other aprotic solvents such as THF and diethyl ether were also tried, but the azide products $\mathbf{4}$ and $\mathbf{1 1}$ were once again not formed in these solvents. The failure of this reaction is presumably, contributed by the low solubility of the sodium azide in the used solvents which allow the competing nucleophile, the chloride anion to attack the diazonium salt once it has been generated. As an effort to avert this problem we 
attempted the use of crown ether, but no improvement was achieved. The recent published elegant source of nucleophilic azide (Scheme 5) (Brase et al 2005) was also tried. However, no reaction was observed under these conditions, and the starting material was isolated as a free amino ester, probably due to proton scavenging by the silicate TBAF complex $\mathbf{1 3}$ which could hamper the diazotization reaction.

Another alternative to circumvent the chloro substitution is to use a less nucleophilic counterion on the ammonium salt. L-valine benzyl ester toluene-4-sulfonate (14) was readily available, and it was used to replace phenylalanine ethyl ester hydrochloride (1) (Scheme 6). Once again, this reaction produced the tosylate $\mathbf{1 6}$ rather than the intended azide product $\mathbf{1 5}$. This implies that the sulfonate group was not neutral enough to avoid its attack on the diazonium salt in place of the less soluble nucleophile, the azide anion.

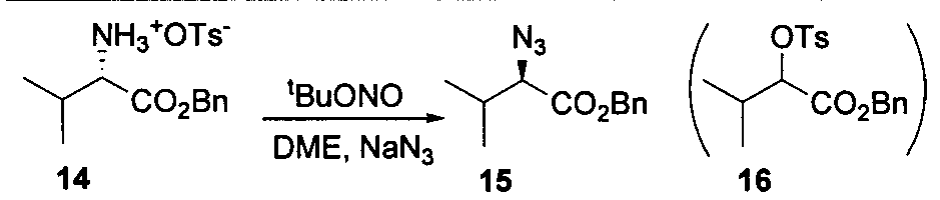

Scheme 6: Diazotization of L-Valine benzyl ester toluene-4-sulfonate (14).

Comparison of optical rotation data of compound 9 with that of enantiomerically pure reference compound $(S)-9$ (Kawamatsu et al 1980) (Table 2) indicated that the diazotization reactions proceed with retention of configuration.

Table 2:Yields and optical properties of the chloro and tosyl substituted products $\mathbf{9 , 1 2}$ and 16

\begin{tabular}{llll}
\hline Compound & $\begin{array}{l}\text { Yield } \\
\text { (\%) }\end{array}$ & Optical activity, $[\alpha] \mathrm{D}$ & Stereoselectivity \\
\hline $\mathbf{9}$ & 92 & $+4.7(\mathrm{c}=2, \mathrm{EtOH})$ & $31 \%$ retention \\
$\mathbf{1 2}$ & 90 & $+5.1\left(\mathrm{c}=2, \mathrm{CHCl}_{3}\right)$ & \\
$\mathbf{1 6}$ & 44 & $+3.6\left(\mathrm{c}=2, \mathrm{CHCl}_{3}\right)$ & \\
\hline
\end{tabular}

Inversion of $\alpha$-amino acids via cyclic aryl disulfonylimides

A third attempt on inversion of amino acids involved the use of cyclic aryldisulfonylimide intermediates. (S)-N,N1,2-benzenedisulfonylimide derivative of phenylalanine ethyl ester 18 (Scheme 7) was obtained in high yield $(88 \%)$ from Lphenylalanine ethyl ester hydrochloride (1) and benzene-1,2-disulfonyl chloride (17) via a previously reported procedure (Sorbye $e t$ al 1998). 


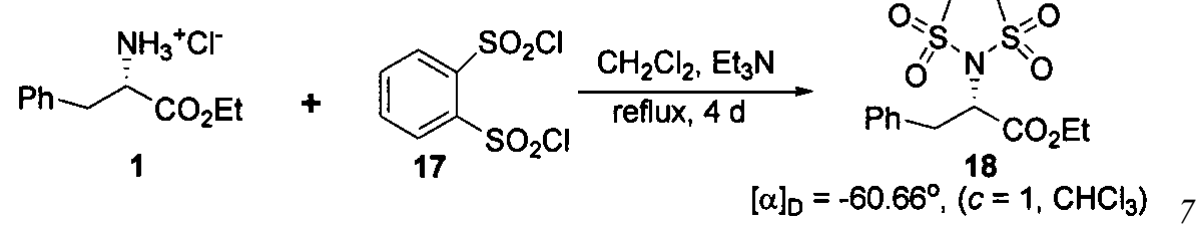

Scheme 7: Synthesis of L-phenylalanine N,N-1,2-benzenedisulfonylimide (18).

The nucleophilic substitution on $(S)$-18 via described procedures (Carlsen 1998, Sorbye et al 1998) was not successful. Surprisingly, this transformation could not be achieved by various reaction conditions (Table 3) which is contrary to the previously observed facile displacement of the related cyclic aryldisulfonylimides (Sorbye et al 1998).
This problem is likely caused by the anionic character of the $\alpha$-carbon. The presence of the disulfonylimide leaving group at $\alpha$ position is expected to umpolung and reverse the nucleophilic property of this carbon. However, it seems that is not the case for this molecule.

Table3: Reaction conditions for nucleophilic substitution of N,N-benzene-1,2disulfonylimide derivative of (S)-phenylalanine ethyl ester (18)

\begin{tabular}{lll}
\hline Entry & Reaction conditions & Comments \\
\hline 1 & $\mathrm{KNO}_{2}, \mathrm{THF}, \mathrm{rt}-$ reflux, $48 \mathrm{~h}$ & No reaction \\
2 & $\mathrm{KNO}_{2}, \mathrm{DMF}, \mathrm{rt}-80{ }^{\circ} \mathrm{C}, 48 \mathrm{~h}$ & No reaction \\
\hline
\end{tabular}

\section{CONCLUSION}

Three methods for preparation of D-amino acids by nucleophilic substitution have been attempted. The $N, N$-disulfonylimide intermediate of phenylalanine ethyl ester was synthesized in high yield and optical purity, but the substitution reaction on this compound was not possible. The nucleophilic substitution on the alternative derivative, the triphenylpyridinium salt was successful. However, the final azide product in this variant was almost racemized. The disadvantage of this reaction is thought to be contributed by the nature of the used substrate and efforts are underway to remove this impediment. Diazotization of amino acid ammonium salts in aprotic solvents gave optically active chloro and tosyl products. However, the problem of the competing ammonium salt counterion remains to be solved.

\section{ACKNOWLEDGEMENT}

I wish to thank Lars Kristian Hansen of Department of Chemistry, University of Tromso for $\mathrm{x}$-ray diffraction experiment.

\section{REFERENCES}

Bajusz S, Csernus VJ, Janaky T, Bokser L, Fekete M and Schally A.V. 1988 New antagonists of LHRH. II. Inhibition and potentiation of LHRH by closely related analogues. Int J Pept Protein Res. 32: 425-435.

Bernatowicz MS, Klimas, CE, Hartl, KS, Peluso M, Allegretto NK, Seiler, SM 1996 Development of Potent Thrombin Receptor Antagonist Peptides J. Med. Chem., 39: 4879-4887. 
Said - Preparation and nucleophilic substitution ...

Bräse S, Gil C, Knepper K, and Zimmermann V 2005 Organic Azides: An Exploding Diversity of a Unique Class of Compounds Angt. Chem. Intl. Edt. 44: 5188 - 5240.

Carlsen PHJ 1998 Benzylation of Alcohols and Phenols with N-(4-methoxybenzyl)-obenzenedisulfonimide Tetrahedron Lett. 39: 1799-1802.

Drauz K 1997 chiral amino acids: a versatile tool in the synthesis of pharmaceuticals and fine chemicals. Helvetica Chimica Acta 51: 310-314.

Hoffman R and Kim H-O 1992 A simple synthetic approach to Cbz-Phe-y(CH[2])Gly-Pro-OMe and related peptide isosteres Tetrahedron 33: 3579-3582.

Katritzky AR, Bapad JB, Blade RJ, Leddy, BP, Nie PL, Ramsden CA and Thind SS 1979 Heterocycles in Organic Synthesis. Part 6. Nucleophilic Displacements of Primary Amino-groups via 2,4,6Triphenylpyridinium Salts J. Chem. Soc., Perkin Trans. 1, 418-432.

Katritzky AR, Marquet J, Lloyd JM, and Keay, JG 1983 Kinetics and Mechanisms of Nucleophilic Displacements with Heterocycles as Leaving Groups. Part 10. Reactions of s-Alkyl Primary Amines with Pyryliums J. Chem. Soc., Perkin Trans. 2, 1435-1441.

Kawamatsu Y, Asakawa H, Saraie T, Mizuno $\mathrm{K}$, Imamiya E, Nishikawa $\mathrm{K}$ and Hamuro $\mathrm{Y}$
1980 Studies on Antihyperlipidemic Agents Arzneim.-Forsch./Drug Res., 30: 751-758.

Rutjes FPJT, Wolf LB and Schoemaker HE 2000 Applications of aliphatic unsaturated non-proteinogenic a-H-a-amino acids $J$. Chem. Soc., Perkin Trans. 1, 4197 - 4212.

Said SA and Fiksdahl A 2001a Formation of chiral aryl ethers from enantiopure amine or alcohol substrates Tetrahedron: Asymmetry, 12: 893-896.

Said SA; Fiksdahl A 2001b Stereseolective transformation of amines via 2,4,6triphenylpyridinium intermediates Tetrahedron: Asymmetry, 12: 1947-1951.

Sørbye K, Tautermann C, Carlsen PH and Fiksdahl A. $1998 \quad N, N-1,2-$ bezenedisulfonylimide, a new cyclic leaving group for the stereoselective nucleophilic substitution of amines. Tetrahedron: Asymmetry 9: 681-689.

Wenger RM 1985 Synthesis of cyclosporine and analogues: structural requirements for immunosuppressive activity Angew. Chem. Int. Ed. Engl., 24, 77-85.

Williams R.M and Hendrix JA 1992 Asymmetric Synthesis of Arylglycines Chem. Rev. 92: 889-917.

Williams RM 1989 Synthesis of optically Acitve $\alpha$-Amino Acids, Vol 7 of Organic Chemistry Series; Baldwin JE and Magnus PD (Eds.); Pergamon Press, Oxford. 